Original Research

\title{
Assessment on the Quality and Environmental Impacts of Composting at Institutional Community Using Life Cycle Assessment Approach
}

\author{
Chee Guan Ng1*, Sumiani Yusoff', Nur Shakirah Binti Kamarul Zaman², \\ Chong Siewhui ${ }^{3}$ \\ ${ }^{1}$ Institute of Ocean and Earth Science, Universiti Malaya, 50603 Kuala Lumpur, Malaysia \\ ${ }^{2}$ Institute of Advanced Studies, Universiti Malaya, 50603 Kuala Lumpur, Malaysia \\ ${ }^{3}$ Department of Chemical and Environmental Engineering, Faculty of Science and Engineering, \\ University of Nottingham, Broga Road, 43500, Selangor, Malaysia
}

Received: 17 October 2019

Accepted: 17 June 2020

\begin{abstract}
Composting is the commonly widespread treatment option in organic fraction of municipal solid waste and agro-industrial by-products. However some arguments have arisen over the years questioning its impact on the environment through gaseous emissions and impurities released from the system. Different composting methods reveal vital differences and the environmental impacts may vary. Hence, the study aims to assess the quality of the compost using passive-aerated static pile method in tropical climate and to study the associated environmental impacts. Data were obtained from an operating small-scaled composting facility corresponding to $1 \mathrm{~kg}$ of food waste as functional unit. The physicochemical properties of the final composts obtained indicate that they were stable and are according to the Malaysian standards. Seven impact categories were assessed and the characterized result showed that all sub systems contributed to all impact categories in different magnitudes. The study clearly resulted by treating food waste and yard waste, it could yield better greenhouse gas savings and providing valuable information contributing to effective climate change policy under Malaysia's settings. Thus, the diversion of FW to composting has considerable potential to result in a significant net climate benefit and offers great potential in establishing a circular food waste management system.
\end{abstract}

Keywords: food waste, composting, passive aerated static pile, GHG mitigation, environmental impacts

*e-mail: cheeguan.ng@um.edu.my 


\section{Introduction}

Food waste can be defined as edible food materials discarded throughout the food supply chain from initial production to final household consumption [1-2]. In 2012, it was reported that Malaysians produced 33,000 tonnes of solid waste daily [3]. The overall waste composition in Malaysia is dominated by municipal solid waste (MSW), corresponding to $64 \%$, followed by industrial waste $(25 \%)$, commercial waste $(8 \%)$ and construction waste $(3 \%)$. In general, MSW in Malaysia consists of $50 \%$ food waste, and $70 \%$ of it is disposed of at landfill sites with households being the primary source of MSW in Malaysia [4-5]. However, scholarly article regarding food waste management and disposal in Malaysia is limited since most published papers would consider food waste as part of the MSW.

At present, landfilling is the main method of waste disposal (80\% usage) in Malaysia. Unlike in many other developed countries, wastes generated from residential, institutional, commercial and industrial sectors are disposed in landfills without any pre-treatment [6-7]. Statistics showed that there are 186 waste disposal sites in operation, out of which only $4 \%$ are considered sanitary, while many of the others are open dump site [8]. Open dump sites are often in bad conditions and operated without proper protective measurements such as lining systems, leachate treatment and gas venting thus contribute significantly to climate change through methane emission in landfill [9-11]. In addition to that, the large amount of untreated food waste materials and the complex biological and physicochemical processes make areas in the proximity of landfills vulnerable, not only to emissions of potential toxic compounds but also to other nuisance such as odor pollution [12]. All these factors have severe impacts in the local environment causing degradation in environmental quality. It has emerged as a potentially viable means by which local governments can reduce the food waste entering landfills. Diverting food waste from landfills will not only conserve limited landfill space, but also help to conserve nutrient resources stored in the food waste. For instance, alternative treatment for the organic fraction of Municipal Solid Waste (OFMSW) is almost exclusively applied in European countries and California where diversion of organics from landfill is enforced by legislation [13].

Composting is one of the common treatment options in solid waste, particularly organic fraction in municipal solid waste and agro-industrial by-products [14]. Literature suggested that compost production contributes to carbon sequestration [15]. However, some arguments have arose over the years questioning its impact on the environment through gaseous emissions and impurities released from the system [16]. Prior to treatment, wastes are transported to composting sites in trucks, which are major contributors of emission and production of greenhouse gases, for instance carbon dioxide. It is evident that carbon dioxide is one of the main causes of global warming and climate change [17]. Moreover, energy consumption for waste handling and active aeration process in largescale composting was considered as one of the major contributors to environmental impact. On the contrary, small-scaled composting plant, of which commonly employs passive-aerated static pile method requires less energy consumption [18]. Hence, these two composting methods present vital differences and hence the environmental impacts may vary [16].

The present study is intended to assess the quality of the compost produced from mixed food waste using passive-aerated static pile method in tropical climate. Secondly, this study aims to quantify life cycle inventory in association to compost production and relevant processes and thirdly, to study their environmental impacts as well as to assess climate change mitigation potential of food waste composting.

\section{Methods and Materials}

Food waste (hereafter referred as FW) was collected from selected restaurants at university campus that serve typical local cuisines. The FW comprises leftovers such as raw fruits and vegetables, rice, unfinished food, raw fish, and meat (as shown in Fig. 1a). Yard waste (hereafter referred as YW), which includes tree cuttings, branches, grass and twigs was collected from

a)

b)

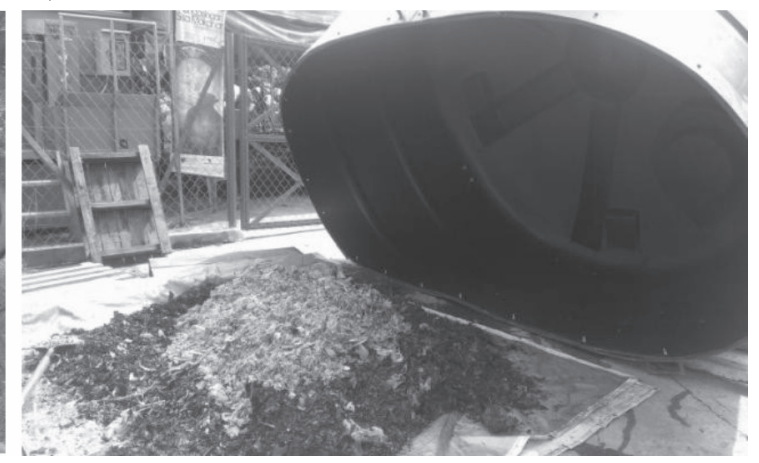

Fig. 1. a) Food waste collected from selected restaurants in university campus; b) setting up of composting pile. 


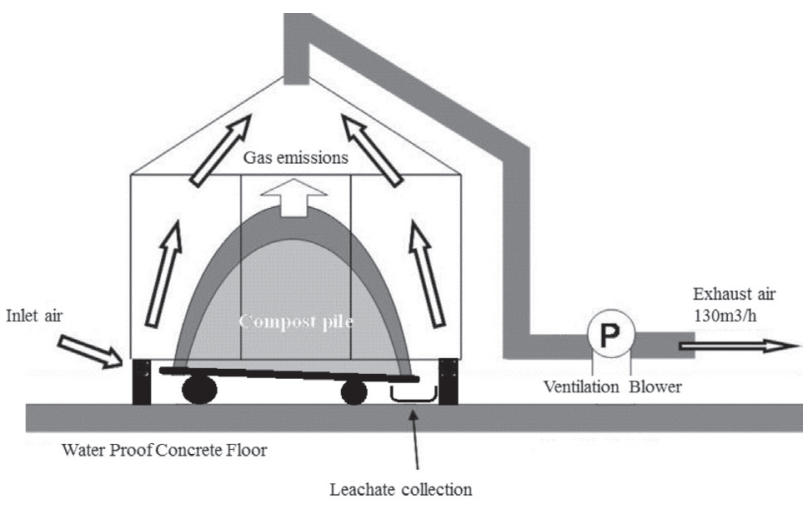

Fig. 2. Schematic design of composting set-up.

Universiti Malaya and was used as bulking agent in order to provide enough porosity to the static pile [19]. The composting process was carried in Universiti Malaya Zero Waste Campaign Center (UMZWC), Kuala Lumpur.

\section{Composting Set-up}

Composting was carried out by using passive aerated static pile method (Fig. 1b). First, the YW was shredded by means of a shredder machine. The pile was constructed with a layer of shredded YW on the ground with thickness of approximately $15 \mathrm{~cm}$, covering a circular area with diameter of $3 \mathrm{~m}$. Then, the collected $\mathrm{FW}$ and $\mathrm{YW}$ were mixed in an average weigh ratio of 2:1 (FW:YW) before loaded onto the YW layer until the pile reached the height of $1.5 \mathrm{~m}$ with total weight of approximately $6,750 \mathrm{~kg}$. The pile was covered to control the moisture content for 100 days. The leachate was collected and recirculated into the pile manually. During the period, the pile was turned manually every week. The experiment was carried out from November 2018 to March 2019. This corresponds to typical hot and moist tropical climate conditions (temperature from $26^{\circ} \mathrm{C}-35^{\circ} \mathrm{C}$ and moderate rainfall). The design layout of the composting is illustrated in Fig. 2.

\section{Institutional-Based Composting Operation}

The composting center in Universiti Malaya, Kuala Lumpur was selected as the reference portrayal for small-scaled composting process due to the availability of equipment and materials. The center produces compost from approximately $200 \mathrm{~kg} / \mathrm{day}$ of $\mathrm{FW}$ and $100 \mathrm{~kg} /$ day of $\mathrm{YW}$ collected from residential colleges and restaurants in the campus. The operation of the composting center is shown in Fig. 3. FW and $\mathrm{YW}$ is collected and transported to the treatment center with average $5.2 \mathrm{~km}$ of distance traveled. Inorganic fractions are removed manually. YW is shredded via a 6-HP wood chipper and subsequently layered on the ground as the base with diameter of $3 \mathrm{pm}$ and thickness of $15 \mathrm{~cm}$. Daily collected FW is weighed before loaded onto the layer of the shredded yard waste. The FW is covered with another layer of shredded YW with thickness of approximately $5 \mathrm{~cm}$. The processes are repeated until the layered static pile reaches $1.5 \mathrm{~m}$ of total height and let composted for 100 days. The compost is then air-dried before ground with a 12-HP grinder (SIMA/FG-400) and stored.

\section{Characterization and Analysis Tests}

$\mathrm{pH}$ was measured using aqueous suspension of the compost samples at 1:10 w/v sample-water ratio. Moisture content was measured using air-oven method at $105^{\circ} \mathrm{C}$. Total organic matter (TOM) and ash content were measured using furnace method at $550^{\circ} \mathrm{C}$. Total organic carbon (TOC) was measured by method suggested by Bahadori and Tofighi [20]. (TKN) was measured using method explained by Jiang et al. [21]. Electricity conductivity (EC) was measured using standard method suggested by Taiwo et al. [22]. Ammonium and Nitrate nitrogen were determined by method suggested by Kim et al. [23]. Total elements in compost were determined by dry-ashing method followed by analysis using ICP.

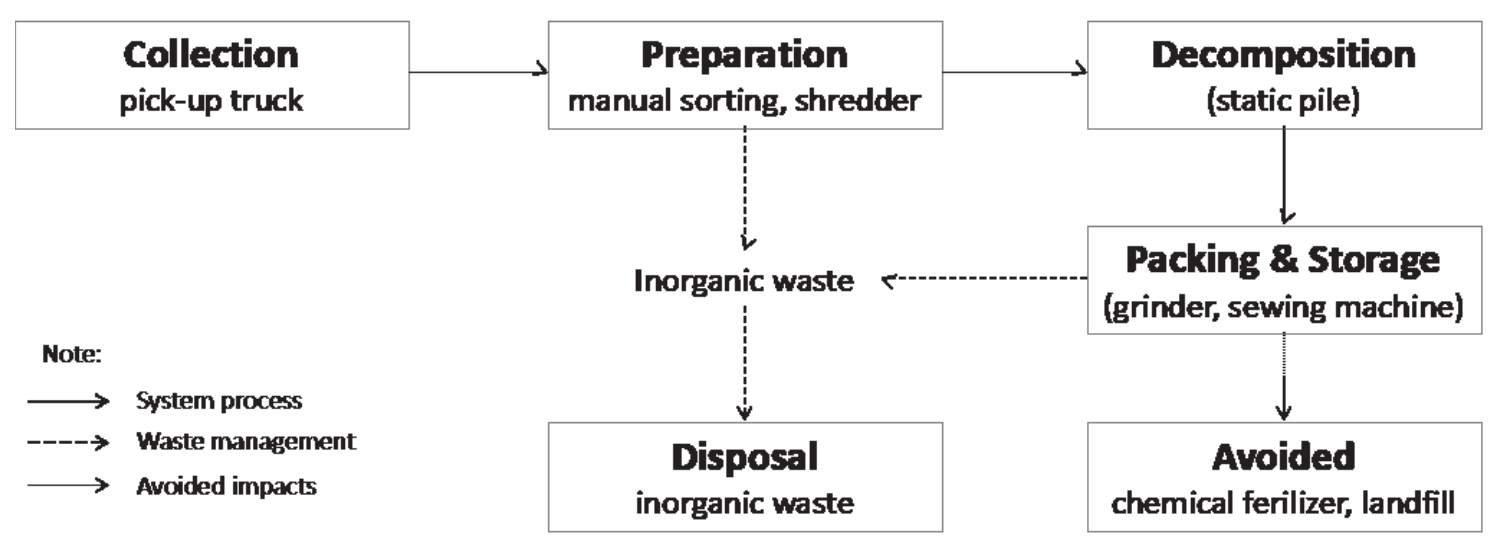

Fig. 3. Process flow of studied small-scaled composting systems. 


\section{Data Origin for Material Flow Analysis}

Emissions and auxiliary materials consumption for FW composting system were obtained from a static composting pile controlled, managed by the authors at the Universiti Malaya (Kuala Lumpur, Malaysia) following the practices recommended by $\mathrm{Ng}$ and Yusoff [24]. In relation to small-scaled composting operation, data were obtained from UMZWC facility: the inventory data was supplied by the plant manager, corresponding to treatment capacity of $300 \mathrm{~kg}$ of $\mathrm{FW}$ on daily basis. The ground plan of UMZWC is illustrated in Fig. 4. It was selected due to its steady state, its adequate technical and environmental characteristics and it generates compost from FW and YW collected from residential colleges and restaurants in the campus.

\section{Environmental Impact Assessment}

LCA framework was applied to quantify the environmental impacts from institutional-based composting process following the ISO 14040 and 14044 standards [25]. The scope of the study is limited to the FW and YW entering the composting site, compost production and disposal of inorganic fractions.

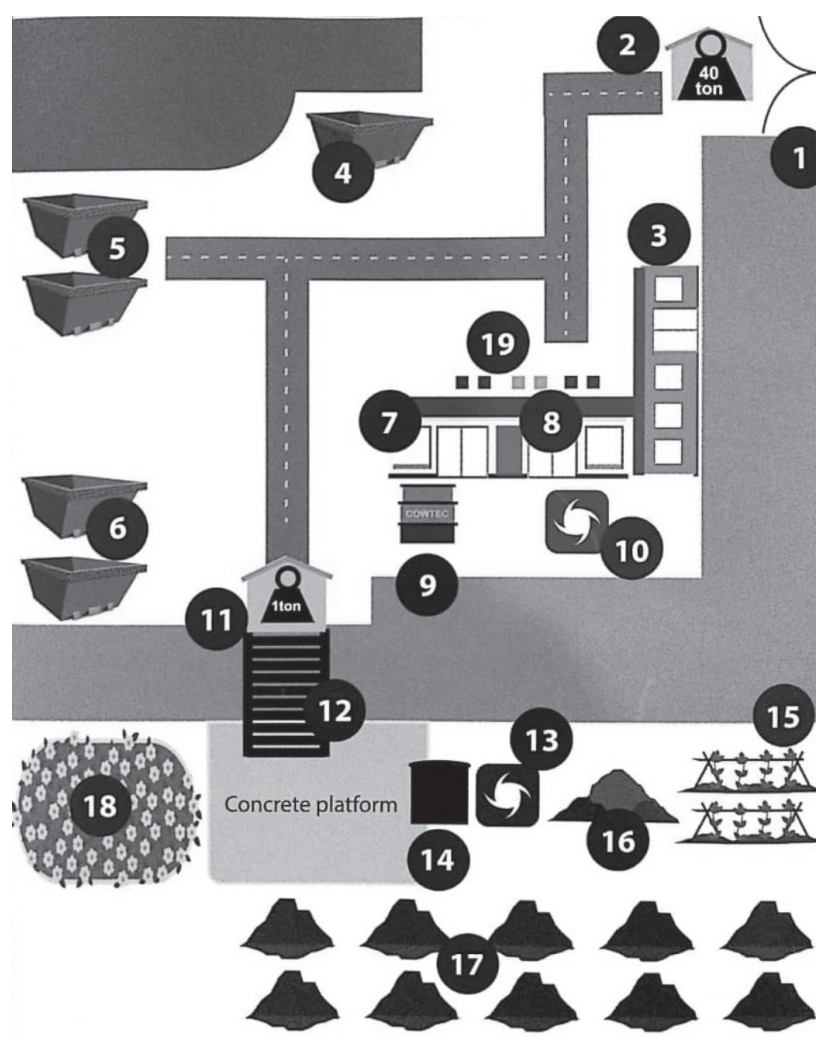

Fig. 4. Ground Plan of Universiti Malaya Zero Waste Campaign Center.

1: entrance; 2: weight bridge office; 3 : workers' room; 4: wood waste; 5: food waste; 6: yard waste; 7: gallery; 8: office; 9: digestor; 10: Shredding area; 11: weighing scale; 12: ramp; 13: compost grinder; 14: storage; 15: organic farm; 16: drying; 17: decomposition area; 18: garden; 19: recycle bin.
The system boundary of the study is illustrated in Fig. 3. The leachate collected is re-circulated into the compost piles, hence waste water treatment process is excluded from the study. Chemical fertilizer avoidance was excluded in the present study due to insignificant amount of chemical fertilizer replacement compared to the total fertilizer consumption in the campus.

The data used is predominantly primary, corresponding to the operation of the composting center from January 2015 till December 2018. Reference for background activities was also made to previous studies and Ecoinvent 3.0 database [26]. Information in respect to feed stock quantity, material balance, energy consumption were obtained from the fieldwork. Gas emissions from the composting process were estimated from previous study [24]. Compost product quality was estimated with reference to $\mathrm{Ng}$ and Yusoff [27]. Background inventory for electricity generation in Malaysia was obtained from Ecoinvent 3. The recycling fraction obtained from the manual sorting process was excluded from the calculations due to insignificant amount of recyclable materials collected. The direct and indirect processes were summarized in Table 1.

Life cycle assessment was performed by using the SimaPro 9.0 software with Centrum voor Milieukunde Leiden (CML) 2000 method which was developed by the Centre of Environmental Sciences at Leiden University [28]. The impact categories used were in agreement with literature studies [29-32]. The impact categories were listed in Table 1.

\section{Result and Discussions}

The results and discussion are categorized into three sections: (1) Physicochemical characteristics of compost; (2) The development of input-output inventory for composting process; and (3) Assessment of Environment Impacts from composting operation.

\section{Physicochemical Characterization of Compost}

Table 2 shows the characteristic comparisons of final composts between present study and several others. The final $\mathrm{C} / \mathrm{N}$ ratio, $\mathrm{pH}$ and moisture content of the compost produced in the present study were acceptable and in agreement with most literature studies. Compost produced contain a sizable proportion of biodegradable organic matter one or more of the major plant nutrients namely nitrogen $(2.39 \%)$, phosphorus $(2.82 \%)$, potassium $(0.21 \%)$ and magnesium $(0.36 \%)$. Compost produced is in agreement ro the Malaysia organic fertilizer standard in respect to moisture content, $\mathrm{C} / \mathrm{N}$ ratio, TOM and TKN requirements. Furthermore, literature suggested $\mathrm{C} / \mathrm{N}$ ratio of final compost to be kept below 25 in order to enhance nitrogen and microbial stability [33-34]. Van Fan et al. recommended that the desired $\mathrm{C} / \mathrm{N}$ ratio for matured compost to be less than 14 [35]. Alternatively, 
Table 1. Life Cycle Inventory and Impact Categories.

\begin{tabular}{|c|c|c|c|}
\hline Process & Scope & Inventory & Impact Categories \\
\hline \multirow{3}{*}{$\begin{array}{l}\text { Waste } \\
\text { collection }\end{array}$} & Diesel consumption & Included & \multirow{18}{*}{$\begin{array}{l}\text { i. abiotic depletion potential } \\
\text { (ADP) } \\
\text { ii. acidification potential } \\
\text { (AP) } \\
\text { iii. eutrophication potential } \\
\text { (EP) } \\
\text { iv. global warming potential } \\
\text { (GWP) } \\
\text { v. ozone layer depletion } \\
\text { potential (ODP) } \\
\text { vi. human toxicity potential } \\
\text { (HTP) } \\
\text { vii. photochemical oxidation } \\
\text { potential (POP). }\end{array}$} \\
\hline & $\begin{array}{l}\text { Diesel production; Exhaust gas emission; Tyre wear emission; Road } \\
\text { wear emission; Brake wear emission }\end{array}$ & Included & \\
\hline & Lorry production; Maintenance & Excluded & \\
\hline \multirow{3}{*}{$\begin{array}{l}\text { Feed stock } \\
\text { preparation }\end{array}$} & $\begin{array}{l}\text { Working hour for shredder machine; Diesel consumption; Maintenance } \\
\text { (lubricating oil and steel blades) }\end{array}$ & Included & \\
\hline & Diesel production; Lubricating oil production; Production of steel alloy & Included & \\
\hline & Manufacturing of shredder; Infrastructure set-up & Excluded & \\
\hline \multirow{3}{*}{$\begin{array}{l}\text { Compost } \\
\text { production }\end{array}$} & Batch compost produced; Electricity consumption & Included & \\
\hline & Gas emissions; Electricity generation (Malaysia) & Included & \\
\hline & Leachate emission; Soil emission; Infrastructure set-up & Excluded & \\
\hline \multirow{3}{*}{ Packaging } & $\begin{array}{l}\text { Working hour for grinding machine; Diesel consumption; Maintenance } \\
\text { (lubricating oil and steel blades) }\end{array}$ & Included & \\
\hline & Diesel production; Lubricating oil production; Production of steel alloy & Included & \\
\hline & $\begin{array}{l}\text { Manufacturing of shredder; Infrastructure set-up; Plastic bag consump- } \\
\text { tion and production }\end{array}$ & Excluded & \\
\hline \multirow{3}{*}{ Disposal } & Amount of inorganic waste disposed & Included & \\
\hline & $\begin{array}{c}\text { Electricity consumption; Leachate treatment; Materials for landfill } \\
\text { operation; Production of materials }\end{array}$ & Included & \\
\hline & Transportation to landfill & Excluded & \\
\hline \multirow{3}{*}{$\begin{array}{l}\mathrm{N} \text { fertiliser } \\
\text { avoidance }\end{array}$} & Amount of $\mathrm{N}$-fertiliser replaced & Excluded & \\
\hline & Production of fertiliser as in urea ammonium nitrate & Excluded & \\
\hline & Land application of compost & Excluded & \\
\hline
\end{tabular}

compost stability can also be determined by using the ratio of the nitrate-N/ammonium-N ratio. Casero et al. suggested that maturity compost is directly proportional to the value of the ratio [36]. Another study by $\mathrm{Wu}$ et al. revealed that the desired maximum concentration of ammonium-N in a matured compost is $400 \mathrm{ppm}$ and the matured compost produced from municipal solid waste has the ratio of $\mathrm{N}-\mathrm{NO}_{3}{ }^{-} / \mathrm{N}-\mathrm{NH}_{4}^{+}$above 6.25 [37]. The increase in the ratio is associated to the degradation of protein to ammonium and further nitrified to nitrate.

The $\mathrm{pH}$ value of compost of the present study is in agreement with previous studies [38], however Guidoni et al. produced food waste compost with higher $\mathrm{pH}$ value by using home-bin composting method [39]. The electrical conductivity of the present study compost is way higher than the rest with only values ranging from 2.51 to $5.18 \mathrm{mS} / \mathrm{cm}$. The percentage of total organic matter of present study is the lowest compared to the other studies, with values ranging from the lowest, $53.9 \%$ [40] to highest, $73.12 \%$ [39]. The present study compost also has the lowest percentage of total organic carbon, only at $14.34 \%$ as compared to other composts that have significantly higher values. Among all the composts, the present study compost has higher percentage of total Kjeldahl nitrogen percentage, at $2.39 \%$ compared to $0.87 \%$ [39]. Similarly, the percentage of moisture in present study compost is the lowest, at $29.54 \%$ whereas the others are between $36.7 \%$ to $62.23 \%$. Next, present study compost has the highest percentage of ash as well, $52.96 \%$ whereas both previous studies by other researchers showed slightly lower values [38, 40]. The $\mathrm{NH}_{4}-\mathrm{N}$ value of present study compost is very much lower than both literature studies' composts which are at $150.5 \mathrm{ppm}$ and $166.1 \mathrm{ppm}$ respectively. The $\mathrm{NO}_{3}-\mathrm{N}$ value of the present study compost is significantly higher than both literature studies, which are at relatively low $82.2 \mathrm{ppm}$ and 96.4 ppm respectively.

\section{Process Inventory}

Table 3 exhibits a summary of life cycle inventory for the small-scaled composting systems, corresponding to $1 \mathrm{~kg}$ of $\mathrm{FW}$ input. The inputs were categorized according to sub systems. Inputs to the institutionalbased composting system include energy, water and auxiliary materials required throughout the scope of the study. However, the manufacturing of the vehicles and construction of the facilities were not included. The outputs quantified were associated to direct gaseous 
Table 2. Final Compost Characterisations and Comparison.

\begin{tabular}{|c|c|c|c|c|c|}
\hline $\begin{array}{l}\text { Standard/ } \\
\text { parameter }\end{array}$ & Present study & {$[38]$} & [39] & {$[40]$} & $\begin{array}{c}\text { Malaysian SIRIM MS } \\
\text { 1517:2012 Standard }\end{array}$ \\
\hline Type & Organic compost & Organic compost & $\begin{array}{l}\text { Food waste } \\
\text { compost }\end{array}$ & $\begin{array}{l}\text { Food waste } \\
\text { compost }\end{array}$ & Organic fertilizer \\
\hline Bulking agent & Yard waste & Biochar & Zeolite & Rice husk & - \\
\hline FW:Bulking agent & $\begin{array}{c}4: 1 \\
(w t / w t)\end{array}$ & $\begin{array}{c}1: 1 \\
(\mathrm{v} / \mathrm{v})\end{array}$ & $\begin{array}{c}1: 4 \\
(w t / w t)\end{array}$ & $\begin{array}{c}1: 1 \\
(\mathrm{v} / \mathrm{v})\end{array}$ & - \\
\hline $\mathrm{pH}$ & 6.6 & 7.0 & 7.5 & 9.28 & - \\
\hline $\mathrm{EC}(\mathrm{mS} / \mathrm{cm})$ & 24.85 & 3.4 & 3.4 & & - \\
\hline TOM $(\%)$ & 47.05 & 54.2 & 53.9 & 73.12 & $>50$ \\
\hline TOC (\%) & 14.34 & - & - & 40.62 & - \\
\hline TKN (\%) & 2.39 & - & - & 0.87 & $>1.5$ \\
\hline Moisture (\%) & 29.54 & 36.7 & 40.8 & 62.23 & $<30$ \\
\hline $\operatorname{Ash}(\%)$ & 52.96 & 45.7 & 46.1 & - & - \\
\hline $\mathrm{P}$ as $\mathrm{P}_{2} \mathrm{O}_{5}(\%)$ & 2.82 & - & - & - & - \\
\hline $\mathrm{K}$ as $\mathrm{K}_{2} \mathrm{O}(\%)$ & 0.21 & - & - & - & - \\
\hline $\mathrm{Mg}$ as $\mathrm{MgO}(\%)$ & 0.36 & - & - & - & - \\
\hline $\mathrm{Ca}(\%)$ & 0.76 & - & - & - & - \\
\hline $\mathrm{Al}(\%)$ & 0.63 & - & - & - & - \\
\hline $\mathrm{Na}(\%)$ & 0.20 & - & - & - & - \\
\hline $\mathrm{Fe}(\%)$ & 0.97 & - & - & - & - \\
\hline $\mathrm{S}(\%)$ & 0.37 & - & - & - & - \\
\hline $\mathrm{Cu}(\mathrm{ppm})$ & 21.49 & - & - & - & - \\
\hline $\mathrm{Mn}(\mathrm{ppm})$ & 160.27 & - & - & - & - \\
\hline $\mathrm{Zn}(\mathrm{ppm})$ & 17.56 & - & - & - & - \\
\hline B (ppm) & 10.70 & - & - & - & - \\
\hline $\mathrm{NH}_{4}-\mathrm{N}(\mathrm{ppm})$ & 5.58 & 150.5 & 166.1 & - & - \\
\hline $\mathrm{NO}_{3}-\mathrm{N}(\mathrm{ppm})$ & 406.82 & 82.2 & 96.4 & - & - \\
\hline
\end{tabular}

emissions mainly from the composting operation, combustion of diesel in the machinery as well as disposal of rejected solid waste from the composting system. The inventory was in agreement with the study by Martínez-Blanco et al. [32], where the input and output flows between industrial composting and home composting were investigated and compared.

\section{Environmental Impact Assessment}

Seven impact categories were included in the present study (Table 1). Emissions of various gases for instance, $\mathrm{CO}, \mathrm{CO}_{2}, \mathrm{NO}_{2}, \mathrm{SO}_{2}, \mathrm{VOCs}$ and $\mathrm{CH}_{4}$ were considered in the transportation activity, particularly through the energy consumption and exhaust gas emissions from transport vehicles. Similarly, preparation and packaging processes contributed on all impact categories. The impacts were mainly attributed to the production of lubricating oil, iron blades and emissions from diesel consumption in the shredder machine which were considered to indirectly impact the local environment. The gaseous emissions from the diesel burning include $\mathrm{CO}, \mathrm{CO}_{2}, \mathrm{CH}_{4}, \mathrm{~N}_{2} \mathrm{O}, \mathrm{NO}_{2}$, $\mathrm{SO}_{2}$, VOC, and particulate matter (PM). Emissions from composting process contributed significantly to the environmental impacts in respect to acidification, euthrophication, global warming, human toxicity and abiotic depletion. The exclusion of biogenic $\mathrm{CO}_{2}$ emission from the composting process was in agreement with the study conducted by Jeong et al. [41] . Finally, the disposal of inorganic waste to landfill has impacted mainly on the environment in terms of HTP, GWP and ADP. The impacts were attributed to gaseous emissions $\left(\mathrm{CO}, \mathrm{CO}_{2}, \mathrm{NO}_{2}, \mathrm{SO}_{2}, \mathrm{VOCs}\right.$, and $\mathrm{CH}_{4}$ ) from landfill operation. Fig. 4 presents the amount of the impacts generated from the system investigated. Generally, the 
Table 3. Input and Output Flows for Compost Production.

\begin{tabular}{|c|c|c|c|c|}
\hline Process & Elements & Flow & Amount & Unit $\left(\mathrm{kg}^{-1} \mathrm{FW}\right)$ \\
\hline \multicolumn{5}{|c|}{ Inputs } \\
\hline \multirow{2}{*}{ Collection } & Transport freight for waste collection & Transport & 0.035 & $\mathrm{tkm}$ \\
\hline & Plastic collection & HDPE & 0.004 & $\mathrm{~g}$ \\
\hline \multirow{4}{*}{ Preparation } & Wood chipper & Steel & 0.149 & g \\
\hline & Lubricating oil consumption & Lubricating oil & 0.005 & $\mathrm{~L}$ \\
\hline & Cutting blade consumption & steel & 0.020 & $\mathrm{~g}$ \\
\hline & Diesel consumption & Diesel oil & 0.001 & $\mathrm{~g}$ \\
\hline \multirow{6}{*}{ Composting } & Electricity consumption (utilities) & Electricity & 9.381 & $\mathrm{kWh}$ \\
\hline & Mixing tool & Iron & 0.133 & g \\
\hline & Gloves & Rubber & 0.011 & g \\
\hline & Shovel & Steel & 0.029 & g \\
\hline & & Wood & 0.016 & g \\
\hline & Moistening water & Tap water & 0.051 & $\mathrm{~L}$ \\
\hline \multirow{4}{*}{ Packaging } & Grinding machine & Steel & 0.200 & g \\
\hline & Lubricating oil consumption & Lubricating oil & 0.008 & g \\
\hline & Cutting blade consumption & Steel & 0.030 & g \\
\hline & Diesel consumption & Diesel oil & 0.002 & $\mathrm{~g}$ \\
\hline \multicolumn{5}{|c|}{ Outputs } \\
\hline \multirow{6}{*}{ Gaseous emission } & Methane & $\mathrm{CH}_{4}$ & 5.454 & $\mathrm{~g}$ \\
\hline & Nitrous oxide & $\mathrm{N}_{2} \mathrm{O}$ & 0.152 & g \\
\hline & Hydrogen sulphide & $\mathrm{H}_{2} \mathrm{~S}$ & 0.285 & g \\
\hline & Nitrogen oxides & NO & 0.245 & g \\
\hline & Carbon monoxide & $\mathrm{CO}$ & 0.069 & g \\
\hline & Ammonia & $\mathrm{NH}_{3}$ & 0.528 & $\mathrm{~g}$ \\
\hline \multirow{2}{*}{ Disposal } & Waste management in landfill & Mixed plastics & 0.020 & $\mathrm{~kg}$ \\
\hline & Transport to landfill & Transport & 0.012 & $\mathrm{tkm}$ \\
\hline
\end{tabular}

treatment preparation process was the main impacting sub systems mainly due to relative larger amount of waste handled prior to weight loss during composting treatment process. Table 5 depicts that all sub systems contributed to all impact categories.

Impacts from material preparation sub system were mainly contributed by burning of diesel in the shredding machine to shred yard waste prior to mixing with food waste. Production of hot-rolled iron-alloy cutting blades due to frequent replacement of the cutting blades during shredding process contributed significantly to abiotic resource depletion. However, the impact from lubricating oil production was marginal due lower frequency of oil replacement per functional unit. $\mathrm{NO}, \mathrm{CO}_{2}, \mathrm{CO}$ and $\mathrm{SO}_{2}$ emissions from transportation sub system were the main contributors to the environmental impacts. Emission of $\mathrm{NH}_{3}, \mathrm{CH}_{4}$ and
$\mathrm{N}_{2} \mathrm{O}$ from composting process were accounted for the impact of AP, EP, HTP and GWP. $\mathrm{CH}_{4}$ emission from landfill is accounted for the global warming impact.

\section{Environmental Impacts between Composting and Landfilling}

Apart from climate change mitigation, composting treatment of FW has shown reduction in the impacts of ADP and HTP. However, the impacts to AP, EP, ODP and POP were higher in composting (as shown in Fig. 5) mainly due to the extra auxiliary materials used, additional use of energy for material preparation as well as the environmentally harmful gaseous emissions from the composting process. The gaseous emissions were in agreement with literature studies [16, 32]. Composting has been found to produce greenhouse gases such as 


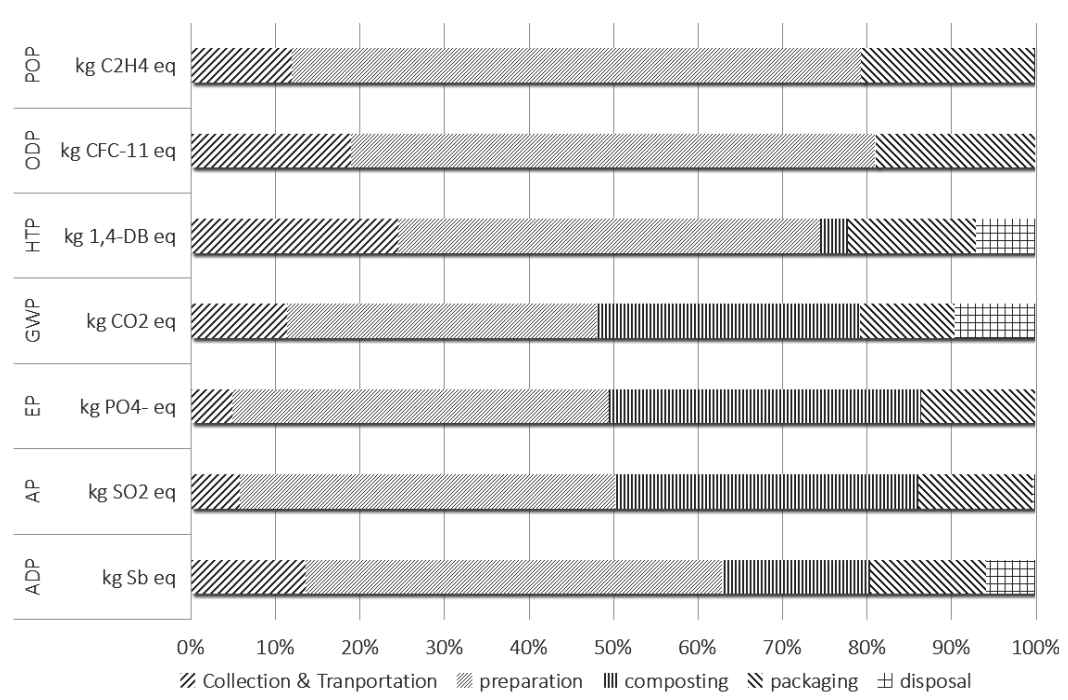

Fig. 5. Environmental profile (characterization results) of composting center in Universiti Malaya.

methane $\left(\mathrm{CH}_{4}\right)$ and nitrous oxide $\left(\mathrm{N}_{2} \mathrm{O}\right)$ [15]. In another study, Boldrin et al. suggested that substances such as volatile organic compounds, ammonia gas, carbon monoxide, methane, nitrogen oxide gas and hydrogen sulfide gas are released in small quantities [42]. Despite their small amount, the substances have the potential to negatively impact air quality [19, 43]. Volatization of ammonia happens during composting causing nitrogen loss in the form of ammonia emissions. This is considered a downside of traditional composting [44-46]. In addition, ammonia gas released from composting can be toxic and worsens the acid rain phenomena as well as ecosystems eutrophication. Carcinogenic substances can be stripped under forced aeration treatments of waste [47]. Composting has also been found to cause an elevation in concentrations of biological air pollution in the form of bio-aerosols [48]. Studies have shown long-term exposure to bioaerosols will lead to adverse health outcomes as well as development of respiratory related symptoms. These affect people working in and living nearby the composting sites [49]. Other than operating conditions, there are several more parameters that contribute to greenhouse gas production and emission through composting. The parameters include environmental conditions such as moisture content, oxygen level and temperature regime and also $\mathrm{C} / \mathrm{N}$ ratio as well as input material texture [50-55].

The greenhouse gases savings were attributed to avoided emissions from alternative treatment and soil $\mathrm{C}$ sequestration. For present study, the baseline treatment included landfill of $\mathrm{FW}$ and $\mathrm{YW}$, which anaerobic conditions led to the formation of $\mathrm{CH}_{4}$. The composting alternative additionally sequestered $\mathrm{C}$ on net. The carbon emission sequestration from composting is illustrated in Fig. 6. Environmental impacts in respect to GWP were modeled and compared between landfill and composting treatment of FW and YW. Subsequently, composting of $\mathrm{FW}$ promotes soil $\mathrm{C}$ sequestration. For instance, carbon is introduced and stored below the ground when compost is applied. Furthermore, carbon uptake from the atmosphere is promoted through soil biomass when compost is applied as soil enhancer [42, 56].

Table 4. Impact Scores (Characterisation).

\begin{tabular}{|c|c|c|c|c|c|c|c|}
\hline $\begin{array}{c}\text { Impact } \\
\text { category }\end{array}$ & Unit & $\begin{array}{c}\text { Collection \& } \\
\text { Transportation }\end{array}$ & Preparation & Composting & Packaging & Disposal & Total \\
\hline $\mathrm{ADP}$ & $\mathrm{kg} \mathrm{Sb}$ eq & $1.29 \mathrm{E}-09$ & $4.71 \mathrm{E}-09$ & $1.68 \mathrm{E}-09$ & $1.30 \mathrm{E}-09$ & $5.70 \mathrm{E}-10$ & $9.54 \mathrm{E}-09$ \\
\hline $\mathrm{AP}$ & $\mathrm{kg} \mathrm{SO}_{2} \mathrm{eq}$ & $5.47 \mathrm{E}-05$ & $4.22 \mathrm{E}-04$ & $3.40 \mathrm{E}-04$ & $1.29 \mathrm{E}-04$ & $4.16 \mathrm{E}-06$ & $9.50 \mathrm{E}-04$ \\
\hline $\mathrm{EP}$ & $\mathrm{kg} \mathrm{PO}_{4} \mathrm{eq}$ & $6.79 \mathrm{E}-05$ & $6.18 \mathrm{E}-04$ & $5.13 \mathrm{E}-04$ & $1.88 \mathrm{E}-04$ & $4.96 \mathrm{E}-07$ & $1.39 \mathrm{E}-03$ \\
\hline $\mathrm{GWP}$ & $\mathrm{kg} \mathrm{CO}_{2} \mathrm{eq}$ & $1.43 \mathrm{E}-02$ & $4.63 \mathrm{E}-02$ & $3.93 \mathrm{E}-02$ & $1.41 \mathrm{E}-02$ & $1.22 \mathrm{E}-02$ & $1.26 \mathrm{E}-01$ \\
\hline $\mathrm{HTP}$ & $\mathrm{kg} \mathrm{1,4-DB} \mathrm{eq}$ & $8.09 \mathrm{E}-04$ & $1.65 \mathrm{E}-03$ & $1.08 \mathrm{E}-04$ & $4.99 \mathrm{E}-04$ & $2.36 \mathrm{E}-04$ & $3.30 \mathrm{E}-03$ \\
\hline $\mathrm{ODP}$ & $\mathrm{kg} \mathrm{CFC}-11$ eq & $2.29 \mathrm{E}-09$ & $7.52 \mathrm{E}-09$ & $1.42 \mathrm{E}-11$ & $2.29 \mathrm{E}-09$ & $3.60 \mathrm{E}-12$ & $1.21 \mathrm{E}-08$ \\
\hline POP & $\mathrm{kg} \mathrm{C}_{2} \mathrm{H}_{4}$ eq & $1.86 \mathrm{E}-06$ & $1.05 \mathrm{E}-05$ & $1.38 \mathrm{E}-08$ & $3.20 \mathrm{E}-06$ & $2.96 \mathrm{E}-08$ & $1.56 \mathrm{E}-05$ \\
\hline
\end{tabular}




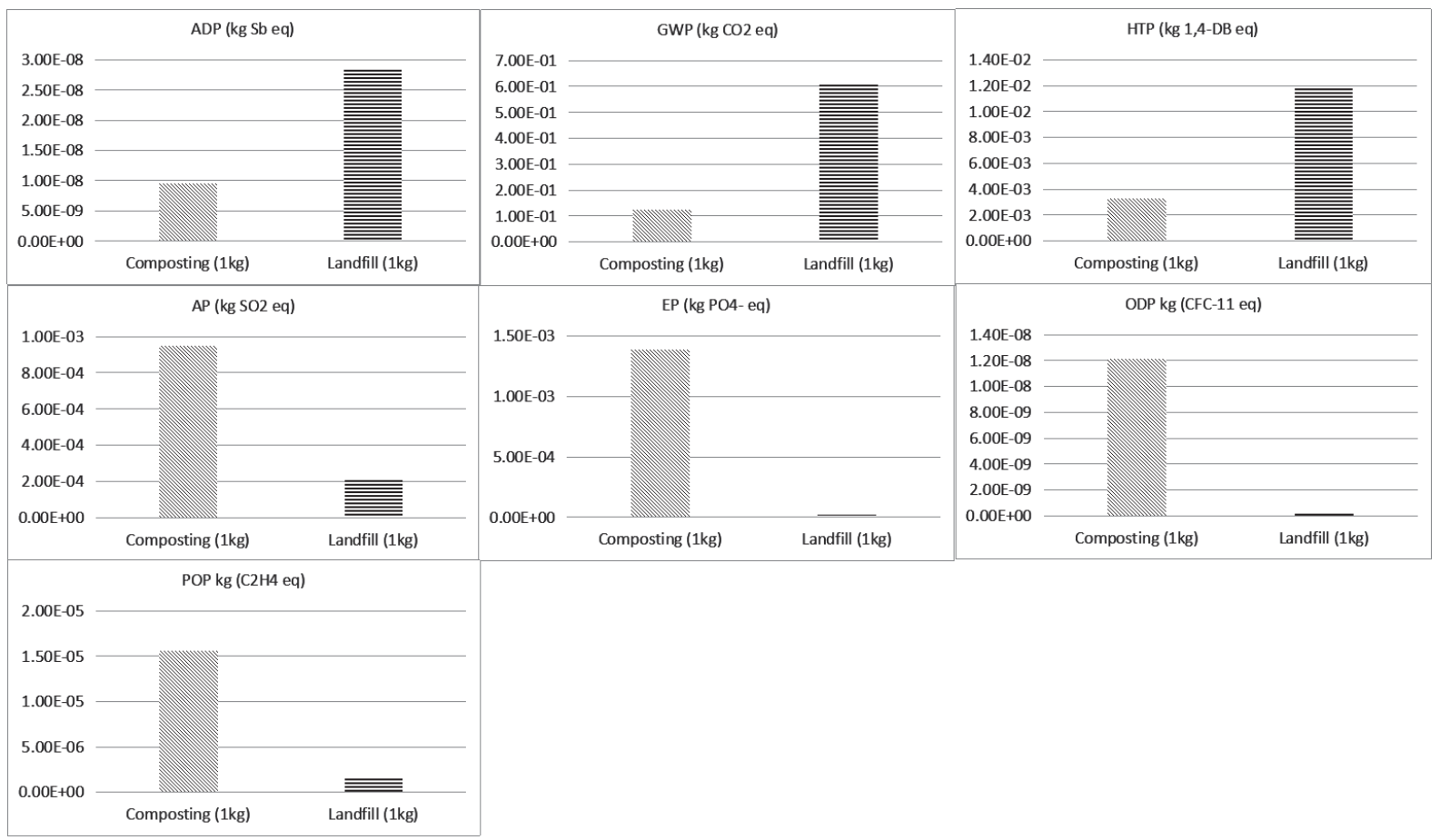

Fig. 6. Comparison between composting and landfill of FW in respect to selected impact categories.

\section{Conclusions}

A life cycle analysis was carried out in order to assess the environmental impacts of passive-aerated static pile composting method. The physicochemical properties of the final composts obtained indicate that they were stable and are according to the Malaysian standards. The material preparation, including shredding machines operation, diesel consumption and gaseous emissions due to diesel combustion were the four main impacting elements in the institutional-based composting system. Generally, the treatment preparation process was the main impacting sub systems mainly due to relative larger amount of waste handled prior to weight loss during composting treatment process. The requirements of the collection transport is avoided in institutional-based composting, thus contribute to lower total transport burdens. In regards to gaseous emissions, ammonia, methane and nitrous oxide emissions for passive-aerated static pile composting were expected to be higher than for active-aerated composting. Material preparation sub system was the main contributor to all impact categories, mainly attributed to burning of diesel in the shredding machine to shred yard waste prior to mixing with food waste. The composting process is likely to emit greenhouse gases, particularly $\mathrm{CH}_{4}$, and thus careful management in association to temperature and moisture control a well as the optimum supply of oxygen, will be required to lower emissions and increase the net benefit from the practice.

The diversion of FW to composting has considerable potential to result in a significant net climate benefit and offers a great potential in establishing a circular food waste management system. As suggested in Fig. 7, a circular chain connecting food waste segregation, collection, transportation, decentralized composting facilities, applications, food product and end users can be established with the co-operations from the government, councils, waste management contractors, industries, non-profit organizations and individuals. Governmental policies and financial support/investment on organic waste management are the key to start the circular loop to aid the establishment of decentralized

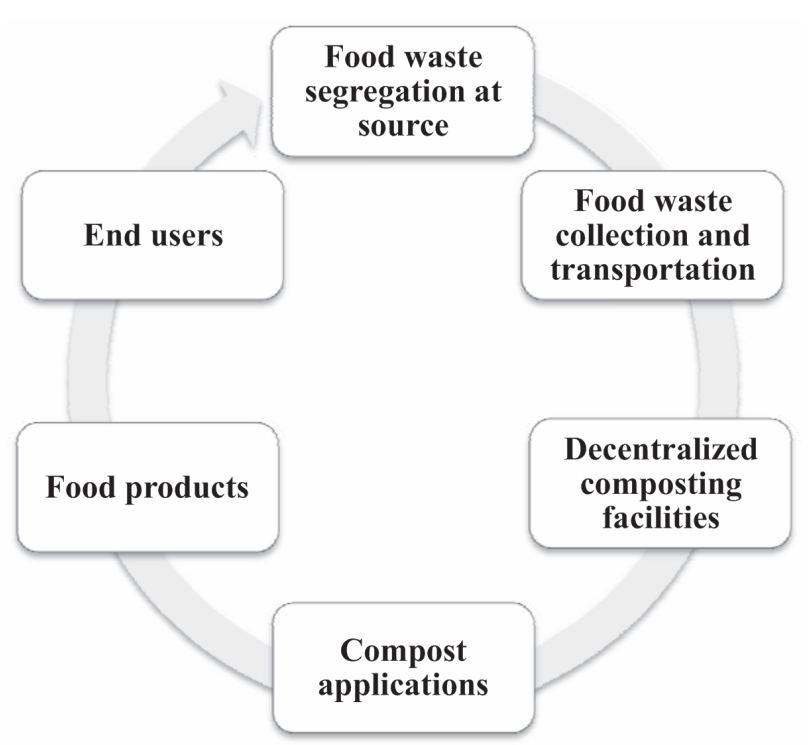

Fig. 7. A circular food waste management approach. 
composting facilities with well-planned waste management strategies. As the composting process is greatly affected by the level of impurities (non-food waste), education and individuals' effort on waste segregation to separate food waste and non-food waste are also one of the vital moves to obtain high-quality composts and increase the market competitiveness for organic composts.

Future research should focus on application of compost on land, soil C storage long-term trends, explore a wider range of future climate scenarios, and test a wider range of feed stocks and practices in composting. Hence, coupled with LCA modeling will provide valuable information and contribute to effective climate change policy for Malaysia working lands.

\section{Acknowledgement}

This research is made possible by the supported grants under Eco-Campus Universiti Malaya, Kuala Lumpur (Living Lab Grant) [LL004-15SUS]; Research University Grant - UMCares [RU013-2017A]; Institute of Ocean and Earth Sciences (IOES) Internal Grant [TU001E-2018]; and the University of Malaya Research Grant (UMRG) [RP023A-16SUS].

\section{Conflict of Interest}

The authors declare no conflict of interest.

\section{References}

1. THYBERG K.L., TONJES D.J. Drivers of food waste and their implications for sustainable policy development. Resources, Conservation and Recycling, 106, 110, 2016 .

2. GUSTAVSSON J., CEDERBERG C., SONESSON U., VAN OTTERDIJK R., MEYBECK A. Global food losses and food waste: Extent, causes and prevention. FAO, Dusseldorf, Germany, 2011.

3. MOH Y.C., MANAF L.A. Overview of household solid waste recycling policy status and challenges in Malaysia. Resources, Conservation and Recycling, 82, 50, 2014.

4. BONG C.P.C., HO W.S., HASHIM, H., LIM, J. S., HO C.S., TAN W.S.P., LEE C.T. Review on the renewable energy and solid waste management policies towards biogas development in Malaysia. Renewable and Sustainable Energy Reviews, 70, 988, 2017.

5. MOH Y. Solid waste management transformation and future challenges of source separation and recycling practice in Malaysia. Resources, Conservation and Recycling, 116, 1, 2017.

6. ISMAIL S.N.S., LATIFAH A.M. The challenge of future landfill: A case study of Malaysia. Journal Toxicology and Environmental Health Sciences (JTEHS), 5 (3), 2400, 2013.

7. TANG K.H.D. Climate change in Malaysia: Trends, contributors, impacts, mitigation and adaptations. Science of the Total Environment, 650, 1858, 2019.
8. HOO P.Y., HASHIM H., HO W.S. Opportunities and challenges: Landfill gas to biomethane injection into natural gas distribution grid through pipeline. Journal of Cleaner Production, 175, 409, 2018.

9. VENKAT K. The climate change and economic impacts of food waste in the United States. International Journal on Food System Dynamics, 2 (4), 431, 2011.

10. DE S., MAITI S., HAZRA T., DEBSARKAR A., DUTTA A. Leachate characterization and identification of dominant pollutants using leachate pollution index for an uncontrolled landfill site. Global Journal of Environmental Science and Management, 2 (2), 177, 2016.

11. LOU X.F., NAIR J. The impact of landfilling and composting on greenhouse gas emissions - a review. Bioresource Technology, 100 (16), 3792, 2009.

12. PALMIOTTO M., FATTORE E., PAIANO V., CELESTE G., COLOMBO A., DAVOLI E. Influence of a municipal solid waste landfill in the surrounding environment: Toxicological risk and odor nuisance effects. Environment International, 68, 16, 2014.

13. CLARKE, W. P. The uptake of anaerobic digestion for the organic fraction of municipal solid waste-push versus pull factors. Bioresource Technology, 249, 1040, 2018.

14. CERDA A., ARTOLA A., FONT X., BARRENA R., GEA T., SÁNCHEZ A. Composting of food wastes: status and challenges. Bioresource Technology, 248, 57, 2018.

15. ANDERSEN J.K., BOLDRIN A., CHRISTENSEN T.H., SCHEUTZ C. Home composting as an alternative treatment option for organic household waste in Denmark: an environmental assessment using life cycle assessmentmodelling. Waste Management, 32 (1), 31, 2012.

16. MARTÍNEZ-BLANCO J., LAZCANO C., CHRISTENSEN T.H., MUÑOZ P., RIERADEVALL J., MØLLER J., ANTÓN A., BOLDRIN A. Compost benefits for agriculture evaluated by life cycle assessment. A Review: Agronomy For Sustainable Development, 33 (4), 721, 2013.

17. CLARK S., KHOSHNEVISAN B., SEFEEDPARI P. Energy efficiency and greenhouse gas emissions during transition to organic and reduced-input practices: Student farm case study. Ecological Engineering, 88, 186, 2016.

18. RASAPOOR M., ADL M., POURAZIZI B. Comparative evaluation of aeration methods for municipal solid waste composting from the perspective of resource management: A practical case study in Tehran, Iran. Journal of Environmental Management, 184, 528, 2016.

19. ADHIKARI B.K., TRÉMIER A., BARRINGTON S., MARTINEZ J., DAUMOIN M. Gas emissions as influenced by home composting system configuration. Journal of Environmental Management, 116, 163, 2013.

20. BAHADORI M., TOFIGHI H. Investigation of soil organic carbon recovery by the Walkley-Black method under diverse vegetation systems. Soil Science, 182 (3), 101, 2017.

21. JIANG T., LI G., TANG Q., MA X., WANG G., SCHUCHARDT, F. Effects of aeration method and aeration rate on greenhouse gas emissions during composting of pig feces in pilot scale. Journal of Environmental Sciences, 31, 124, 2015

22. TAIWO A.M., GBADEBO A.M., OYEDEPO J.A., OJEKUNLE Z.O., ALO O.M., OYENIRAN A.A., ONALAJA O.J., OGUNJIMI D., TAIWO O.T. Bioremediation of industrially contaminated soil using compost and plant technology. Journal of Hazardous Materials, 304, 166, 2016. 
23. KIM J.K., LEE D.J., RAVINDRAN B., JEONG K.H., WONG J.W.C., SELVAM A., KARTHIKEYAN O.P., KWAG J.H. Evaluation of integrated ammonia recovery technology and nutrient status with an in-vessel composting process for swine manure. Bioresource Technology, 245, 365, 2017.

24. NG C.G., YUSOFF S. Assessment of GHG emission reduction potential from source-separated organic waste (SOW) management: case study in a higher educational institution in Malaysia. Sains Malaysiana, 44 (2), 193, 2015.

25. FINKBEINER M. The international standards as the constitution of life cycle assessment: the ISO 14040 series and its offspring. In Background and Future Prospects in Life Cycle Assessment (pp. 85-106). Springer, Dordrecht, 2014.

26. WERNET G., BAUER C., STEUBING B., REINHARD J., MORENO-RUIZ E., WEIDEMA B. The ecoinvent database version 3 (part I): overview and methodology. The International Journal of Life Cycle Assessment, 21 (9), 1218, 2016.

27. NG C.G., YUSOFF S. Life cycle inventory of institutional medium-scaled co-composting of food waste and yard waste in tropical country. Sains Malaysiana, 44 (4), 517, 2015b.

28. LAMNATOU C., NICOLAÏ R., CHEMISANA D., CRISTOFARI C., CANCELLIERI D. Biogas production by means of an anaerobic-digestion plant in France: LCA of greenhouse-gas emissions and other environmental indicators. Science of the Total Environment, 670, 1226, 2019.

29. AVADÍ A. Screening LCA of French organic amendments and fertilisers. The International Journal of Life Cycle Assessment, 1, 2020.

30. CHEVAKIDAGARN P. Composting system improvement by life cycle assessment approach on community composting of agricultural and agro industrial wastes. Indonesian Journal of Environmental Management and Sustainability, 2 (3), 69, 2018.

31. LEIVA F.J., GARCÍA J., MARTÍNEZ E., JIMÉNEZ E., BLANCO J. Scenarios for the reduction of environmental impact in Agaricus bisporus production. Journal of Cleaner Production, 143, 200, 2017.

32. MARTÍNEZ-BLANCO J., COLÓN J., GABARRELL X., FONT X., SÁNCHEZ A., ARTOLA A., RIERADEVALL J. The use of life cycle assessment for the comparison of biowaste composting at home and full scale. Waste Management, 30 (6), 983, 2010.

33. BARRETT J.E., BURKE I.C. Potential nitrogen immobilization in grassland soils across a soil organic matter gradient. Soil Biology and Biochemistry, 32 (11-12), 1707, 2000.

34. AN T., SCHAEFFER S., LI,S., FU S., PEI J., LI H., ZHUANG J., RADOSEVICH M., WANG J. Carbon fluxes from plants to soil and dynamics of microbial immobilization under plastic film mulching and fertilizer application using $13 \mathrm{C}$ pulse-labeling. Soil Biology and Biochemistry, 80, 53, 2015.

35. VAN FAN Y., LEE C.T., KLEMEŠ J.J., CHUA L.S., SARMIDI M.R., LEOW C.W. Evaluation of Effective Microorganisms on home scale organic waste composting. Journal of Environmental Management, 216, 41, 2018.

36. CESARO A., BELGIORNO V., GUIDA M. Compost from organic solid waste: Quality assessment and European regulations for its sustainable use. Resources, Conservation and Recycling, 94, 72, 2015.
37. WU S., SHEN Z., YANG C., ZHOU Y., LI X., ZENG G., AI S., HE H. Effects of $\mathrm{C} / \mathrm{N}$ ratio and bulking agent on speciation of $\mathrm{Zn}$ and $\mathrm{Cu}$ and enzymatic activity during pig manure composting. International Biodeterioration \& Biodegradation, 119, 429, 2017.

38. WAQAS M., NIZAMI A.S., ABURIAZAIZA A.S., BARAKAT M.A., ISMAIL I.M.I., RASHID M.I. Optimization of food waste compost with the use of biochar. Journal of Environmental Management, 216, 70, 2018.

39. GUIDONI L.L.C., MARQUES R.V., MONCKS R.B., BOTELHO F.T., DA PAZ M.F., CORRÊA L.B., CORRÊA É.K. Home composting using different ratios of bulking agent to food waste. Journal of Environmental Management, 207, 141, 2018.

40. WAQAS M., NIZAMI A.S., ABURIAZAIZA A.S., BARAKAT M.A., ASAM Z.Z., KHATTAK B., RASHID M.I. Untapped potential of zeolites in optimization of food waste composting. Journal of Environmental Management, 241, 99, 2019.

41. JEONG S.T., CHO S.R., LEE J.G., KIM P.J., KIM G.W. Composting and compost application: Trade-off between greenhouse gas emission and soil carbon sequestration in whole rice cropping system. Journal of Cleaner Production, 212, 1132, 2019.

42. BOLDRIN A., ANDERSEN J.K., MØLLER J., CHRISTENSEN T.H., FAVOINO E. Composting and compost utilization: accounting of greenhouse gases and global warming contributions. Waste Management \& Research, 27 (8), 800, 2009.

43. HRAD M., BINNER E., PIRINGER M., HUBERHUMER M. Quantification of methane emissions from full-scale open windrow composting of biowaste using an inverse dispersion technique. Waste Management, 34 (12), 2445, 2014.

44. AWASTHI M.K., WANG Q., HUANG H., REN X., LAHORI A.H., MAHAR A., ALI A., SHEN F., LI R., ZHANG Z. Influence of zeolite and lime as additives on greenhouse gas emissions and maturity evolution during sewage sludge composting. Bioresource Technology, 216, 172, 2016.

45. JIANG J., HUANG Y., LIU X., HUANG H. The effects of apple pomace, bentonite and calcium superphosphate on swine manure aerobic composting. Waste Management, 34 (9), 1595, 2014.

46. YANG F., LI G., SHI H., WANG Y. Effects of phosphogypsum and superphosphate on compost maturity and gaseous emissions during kitchen waste composting. Waste Management, 36, 70, 2015.

47. CHENG Z., SUN Z., ZHU S., LOU Z., ZHU N., FENG L. The identification and health risk assessment of odor emissions from waste landfilling and composting. Science of the Total Environment, 649, 1038, 2019.

48. DOUGLAS P., HAYES E.T., WILLIAMS W.B., TYRREL S.F., KINNERSLEY R.P., WALSH K., O'DRISCOLL M., LONGHURST P.J., POLLARD S.J., DREW G.H. Use of dispersion modelling for Environmental Impact Assessment of biological air pollution from composting: Progress, problems and prospects. Waste management, 70, 22, 2017.

49. PEARSON C., LITTLEWOOD E., DOUGLAS P., ROBERTSON S., GANT T.W., HANSELL A.L. Exposures and health outcomes in relation to bioaerosol emissions from composting facilities: a systematic review of occupational and community studies. Journal of Toxicology and Environmental Health, Part B, 18 (1), 43, 2015. 
50. GRIGATTI M., BARBANTI L., HASSAN M.U., CIAVATTA C. Fertilizing potential and $\mathrm{CO}_{2}$ emissions following the utilization of fresh and composted food-waste anaerobic digestates. Science of the Total Environment, 698, 134198, 2020.

51. GUO R., LI G., JIANG T., SCHUCHARDT F., CHEN T., ZHAO Y., SHEN Y. Effect of aeration rate, $\mathrm{C} / \mathrm{N}$ ratio and moisture content on the stability and maturity of compost. Bioresource Technology, 112, 171, 2012.

52. LIU D., ZHANG R., WU H., XU D., TANG Z., YU G., XU Z., SHEN Q. Changes in biochemical and microbiological parameters during the period of rapid composting of dairy manure with rice chaff. Bioresource Technology, 102 (19), 9040, 2011.

53. AMLINGER F., PEYR S., CUHLS C. Green house gas emissions from composting and mechanical biological treatment. Waste Management \& Research, 26 (1), 47, 2008.

54. HE Y., INAMORI Y., MIZUOCHI M., KONG H., IWAMI N., SUN T. Nitrous oxide emissions from aerated composting of organic waste. Environmental Science \& Technology, 35 (11), 2347, 2001.

55. EKLIND Y., SUNDBERG C., SMÅRS S., STEGER K., SUNDH I., KIRCHMANN H., JÖNSSON H. Carbon turnover and ammonia emissions during composting of biowaste at different temperatures. Journal of Environmental Quality, 36 (5), 1512, 2007.

56. RYALS R., HARTMAN M.D., PARTON W.J., DELONGE M.S., SILVER W.L. Long-term climate change mitigation potential with organic matter management on grasslands. Ecological Applications, 25 (2), 531, 2015. 